\title{
Apoptosis Regulator BAX
}

National Cancer Institute

\section{Source}

National Cancer Institute. Apoptosis Regulator BAX. NCI Thesaurus. Code C17699.

Apoptosis regulator BAX (192 aa, $\sim 21 \mathrm{kDa}$ ) is encoded by the human BAX gene. This

protein plays a role in both apoptosis and protein-protein interactions. 